\title{
Yazarın Niyeti Işığında Bir Bağlam Çözümlemesi: "Mesut İnsanlar Fotoğrafhanesi”
}

\author{
ESRA KÜRÜM*
}

\begin{abstract}
ÖZ
Ziya Osman Saba (1910 - 1957), Yedi Meşale Topluluğunun kurucularından biri olarak tanınmıştır. Asıl ününü şiirleri ile kazanmış olmasına rağmen onun hikâyeleri de dikkate değerdir. Çocukluğu ülke için oldukça buhranlı senelere tekabül etmesine karşın dedesinin konağında bütün bu bunalımdan uzak mutlu ve huzurlu bir ortamda geçmiştir. Ancak, annesinin ölümü ve onu takip eden bir dizi sıkıntı ile birdenbire büyümek zorunda kalmıştır. Bu bakımdan Saba'nın hem şiirleri hem hikâyeleri çocukluğunun mutlu, huzurlu aile ocağına duyulan özlemle bir iç çekişi yansıtır. "Mesut İnsanlar Fotoğrafhanesi" yazarın ilk eşinden boşandığı ve mutlu bir yuvanın özlemini duyduğu bir dönemde kaleme aldığı hikâyesidir. Yazarın bu özlemi, hikâyenin bağlamına yerleştirdiği niyet ile ilgili değerler vasıtasıyla çözümlenmeye çalışılacaktır. Hikâyede yazarın asıl niyeti çözülmeye çalışılacak ve niyetini ifade etmek için anlatım değerini kurgusuna yerleştirme biçimi irdelenecektir. Hikâyeye anlatım değerleri açısından baktığımızda sadece işinden çıkıp vitrinleri seyrederek yürüyen ve yolu bir fotoğraf stüdyosuna varan kahramanın fotoğraf çektiremeden stüdyodan çıkışını görmekteyiz. Ancak hikâyeyi yazarın niyetini açı̆̆a çıkaran ifadeleri açısından okuduğumuzda, hikâyede yazarın yaşamına ilişkin ipuçlarıyla anlam kazanarak açılan katmanları görebilmekteyiz.
\end{abstract}

Anahtar sözcükler: Hikâye, Anlatım ve Niyetle İlgili Değerler, Ziya Osman Saba, Mesut İnsanlar Fotoğrafhanesi

* Dr. Öğr. Üyesi, Bitlis Eren Üniversitesi, Türk Dili ve Edebiyatı Bölümü, Bitlis/Türkiye E-posta: esra-kurum@hotmail.com

Makale Gönderim Tarihi: 02.11.2017 • Makale Kabul Tarihi: 04.06.2018 


\section{ABSTRACT \\ A Context Analysis Of Author's Intention: “A Photographer's Studio For The Merry Men”}

Ziya Osman Saba (1910-1957), is known as one of the founders of "the Seven Torch" group. His stories are noteworthy, although he has earned his fame with his poems. Saba who had lived in a happy childhood in his grandfather's estate, away from all this depression even though her childhood passed through the years as an economic depression for the country. He had to abruptly grow up due to his mother's death and aftermath of his lost an array of difficulties. In this respect, Saba's both poems and stories reflect a sigh for a happy, peaceful family's childhood. "A Photographer's Studio for the Merry Men" is the story which was written by Saba when he got divorced from his first wife and it was the period of his life while he was longing for a happy life. His feeling about missing and values related to the intention that he placed in the context of the story will be tried to analyze. The real intention of the writer in the story will be tried to be solved and the way of expression that he used to express his intention will also be examined. From the point of view of narrative values, we see that the protagonist who just walked out of his workplace and went window-shopping and reached the way to a photography studio and he left the studio without having a photo taken. However, when we read the story in terms of nuances that he placed values related to the intention in the context of the story, we can see the opening layers of the story that have become meaningful with the hints of the writer's life.

Keywords: Story, Narrative and Intentional Values, Ziya Osman Saba, A Photographer's Studio For The Merry Men

Edebi sanatlar, her ne kadar toplumun tarihi ve kültürel yaşantısına paralel bir seyir izlemekteyse de unutmamak gerekir ki edebiyat; bu tarihi ve kültürel ortamın, toplumun içinde yaşayan bir birey olan yazara çağrıştırdığını yansıtmaktadır. Bu bakımdan edebi eser, yazarı besleyen her türlü tesirin esere ve dolayısıyla topluma yansımasıdır. Edebiyat, toplumla, milletle anılsa dahi bireysel bir duygulanımın mahsulü olması sebebiyle her daim bir yönüyle ferdidir. Edebi eser değerlendirilirken önce yazar, ardından yazarın mensubu olduğu millet veya toplumun yaşantısı ve değerleri incelenir. Bu bakımdan bütün yazarların toplumu anlatmasını ya da toplumun o devirde maruz kaldığı bunalımları işlemesini beklemek haksızlık olacaktır. Zira her ne kadar yazar kendisini toplumdan tecrit etmiş görünürse görünsün toplumun genel ruh hali ve yazarın milli benliği ile taşıdı̆̆ 1 kolektif şuuraltı miras eserine, alt metin olarak olsun, yansıyacaktır. 
Ziya Osman Saba, milletin içte ve dışta ağır sınavdan geçtiği zor kuşağın neslidir. Kırk yedi yıllık yaşamı savaşlar ve karışıklıkların olduğu bir çağa tanıklıkla geçmiştir. Ancak ailesinin sunduğu imkânlar ve yalı yaşantısı onun bu hadiseleri birebir görerek yaşayan bir çocukluk geçirmesine mâni olmuştur. Sekiz yaşına kadar çok mutlu bir çocukluk yaşayan Saba, annesinin ölümüyle ilk ciddi travmasını yaşar. "Annesinin ölümüyle, bir anda kaybettiği mutlu çocukluk dünyasının ardından bir ömür boyu ağlayacaktı»” (Kırcı 2010: 37). Hayatın en önemli gerçeği olan ölüm ile böylece tanışan Saba, öğrenim hayatına Galatasaray Sultanisi'nde başlamış ve ilk şiirlerini de burada yazmışırı. Annesinin ölümü için yazdığı bu ilk şiirleri siyah kaplı bir defterde toplamıştır. İlk sayfasına "Hissiyatlarım" başlı̆̆ koyduğu bu defteri daha sonra yakacaktır (Kırc1 2010: 25). Ziya Osman Saba’nın, kendisini bir kabuk gibi saran, dışardaki hayatın her türlü gerçekliğinden koruyan yalıdaki çocukluk günleri annesinin ölümü gerçeği ile sona ermiştir. Dışarıdaki hayatın katı gerçekleri ve üzüntüsünden de çocukluğunun mesut günlerine sığınarak korunmaya çalışır. Onun, geleceğin güzel günler getireceğine olan inancı zayıftır. Bu bakımdan hayatındaki en büyük çatışma geçmişinin güzelliklerine özlemi ile geleceğin getireceği karanlık günlere duyulan endişesi arasındadır (Kırc1 2010: 26).

Ziya Osman, henüz yirmi bir yaşında iken aşk ile bağlandığı amcasının kızı (Miyasoğlu 1999: 2) Nermin Hanımla evlenmiş ancak psikolojik rahatsızlıkları bulunan eşiyle hayal ettiği mutluluğu bulamamıştır. On yılı aşkın bir süre devam eden evliliğini daha ziyade sürdürememiş, 1941 yllında üzülerek ve istemeyerek de olsa eşinden boşanmıştır. Çalışmamıza konu olan "Mesut İnsanlar Fotoğrafhanesi”nin de yazıldığı bu dört yıllık süre içinde Saba, morali bozuk olarak bir süre yalnız ve derbeder bir yaşam sürmüştür. Yüksekkaldırım'ın Beyoğlu'na açılan sokaklarından birinde ve bir Yahudi mahallesinde daracık bir apartmanın küçük bir dairesinde tek başına oturmaktadır. Bekâr hayatının verdiği dağınıklık ve yalnızlık hissiyle olmalı bu dönemde kılık ve kıyafetiyle de pek ilgilenmemektedir (Kırcı 2010: 31).

Ziya Osman Saba, İstanbul Üniversitesi Hukuk Fakültesini okurken bir taraftan da Cumhuriyet gazetesinin muhasebe işlerine bakmıştır. 1938'de Emlak Bankasında çalışmaya başlamış ve 5 yıl süreyle burada mesaisine devam etmiştir. Ülkenin savaşa girme ihtimalinden dolayı ikinci kere ihtiyat askerliği yaptıktan sonra yeniden bankadaki işine dönmüş ve burada çalışan Rezzan Hanımla evlenmiştir (Miyasoğlu 1999: 2). Yaşadığı kayıpların yıprattı̆̆ı hassas bir ruh hâline sahip olan yazar, 1950 yılında bir kalp krizi geçirerek işini bırakmak zorunda kalmıştır. Bu tarihten itibaren evinden çıkmayan Saba, 
1957 yılında geçirdiği bir diğer kriz sonucunda hayata gözlerini yummuştur (Miyasoğlu 1999: 2).

Yazmaya şiirle başlayan Ziya Osman Saba, zaman zaman nesre de yönelmiştir. Onun yazdığı ilk hikâyesi, daha sonra yazdığı diğer hikâyelerini de topladığ 1 eserine de adını verecek olan "Mesut İnsanlar Fotoğrafhanesi"dir. ${ }^{1}$ Behçet Necatigil, Saba’nın hikâyeciliğini, "Hayatının dönemlerine göre sıralanırsa şairin biyografisini kronolojik bir gelişim içinde bütünleyecek olan, hepsi de otobiyografik ve içtenlikle dolu bu hâtıra - hikâyeler, uzun cümleli kuruluşları ve ayrıntılar üzerindeki ssrarlarıyla nesrimizde Abdülhak Şinasi Hisar yolunun ve üslûbunun bir devamıdır." şeklinde değerlendirmektedir (2003: 272). Ziya Osman Saba, Türk nesrinde sadece bir yazara hayrandır, o da Abdülhak Şinasi Hisar'dır. Behçet Necatigil'in de yukarıda tespit ettiği gibi Yaşar Nabi de Ziya Osman'ın nesrinde yer yer Hisar tesiri gördüğünü söylemiştir. Ancak Ziya Osman'a göre Hisar gibi yazmak mümkün değildir (Saba 2004: 265). Ziya Osman hakkında yazılmış yazılarda en çok vurgulanan şey onun hayata bakışındaki munis tavır ve alçakgönüllülüğüdür. Ziya Osman Saba hikâyelerini sanatsal kaygilarla kaleme almadığı için hikâyelerdeki samimi söyleyiş ve sohbet tavr1 okuyucuyu hemen kendisine çeker. "Ziya Osman Saba'nın hikâyeleri klasik hikâyenin biçim ve anlatım özelliklerini taşımaz. Yazarın her hangi bir olay anlatmak, okuyucuyu şaşırtmak gibi bir amacı yoktur, Saba'nın hikâyeleri bu yönüyle modern hikâyeye yaklaşır. Yazar, yaşamının kendisinde iz bırakmış anlarını okuyucusuyla paylaşır, bir nevi rahatlamak için yazar." (Uygur 2005: 47). Ziya Osman Saba, nesirlerini bir türün kalıbı içerisinde sıkıştırmaktan ziyade samimi ve gerçekçi olmayı yeğlemiştir bu durum onun özellikle nesirlerinin türü ile ilgili ihtilafa da yol açabilmektedir. Cevdet Kudret, hikâyelerinde konu olarak sadece ve yakın çevresini anlattığı için Saba'nın hikâyelerine "hatıralarının tespiti" nazarıyla bakmakta ve bu hikâyeleri "otobiyografik hikâyeler" olarak adlandırmaktadır. Bununla birlikte Saba’nın hikâyeciliğini ele alan kaynaklarda yazarın Değişen İstanbul adlı eserinin türü ile ilgili olarak yapılan şu yanlı̧şa dikkat çekmektedir: "Hemen bütün kaynaklarda, yazarın Değiş̧en İstanbul adlı kitabı da hikâye kitabı diye anılmış ise de, oradaki yazılar, bütünüyle anı ve izlenimlerden oluştuğu için onları hikâye sayma olanağı yoktur.” (Kudret 2009: 130).

Bu yönüyle Saba'nın hikâyeleri hakkında anı-hikâye tarzında kurgulanmıştır demek yanlış olmayacaktır. Ancak bu kurgular, anılardan yola çıkılmış olmasına rağmen bireysel duygulanımları yansıtmaktan ziyade herkesin kendisinden bir iz bulabileceği kadar da evrenseldir. "Anılarını anlattığı hikâyelerinde, kendisi ve en yakınlarından seçtiği kimseler, kişileri oluştururlar. Yaradılışının çeşitli özellikleriyle onu buluruz karşımızda. Yaptı̆̆ı psikolojik çözümleme- 
lerde, kendi çeşitli duygularını yansıtırken çok kez duyup da açıklayamadığımız duygularımızı dile getirmiş olur." (Önertoy 1979: 83).

Ziya Osman memleket insanını tanımadığı için hikâyelerine hikâyedir diyememektedir. Onları nesir ya da hikâyemsi yazılar olarak adlandırmaktadır. $\mathrm{Bu}$ durum onun hayatının en önemli yerini işgal eden çocukluğunun yalıda halktan uzakta geçmiş olmasından ve yine tevazuundan kaynaklanmaktadır. Saba, hikâye yazmanın yeterince gözlem yapamamış biri için oldukça çetin bir iş olduğunu vurgulamaktadır. "Bilmem dikkat ettiniz mi yukarıda nesir veya hikâyemsi yazılar dedim. Zira hikâye yazmanın zorluğunu, hele benim gibi memleket, insan tanımamışlar için imkânsızlığını bildiğimden yazdıklarıma hikâye demeye bir türlü dilim varmıor; yalnız Mesut İnsanlar Fotoğrafhanesini okumak zahmetine katlanacaklardan ricam, yadırgayacakları parçaları da bir ömrün "hikâye" olamamış ama yine de birer hikâyesi saymalarıdır" (2004: 265).

Ziya Osman, zor geçen hayatının sıkıntılarından çocukluğunun mutlu günlerine ya da ev hayatının huzuruna sığınarak kurtulmaya çalışmaktadır. Hikâyelerinde, şiirlerinde ve anılarında hep eşyalara sinen hatıraları ve o eşyaların kazandığı yeni anlamları görmekteyiz. Bir örnek olmak üzere onun "Şiltem" başlıklı yazısını gösterebiliriz (Saba 2004: 154). Bu yazısında Saba, üzerinde on iki sene yattığı şiltenin onun için çağrıştırdığı manayı çok derinden hissederek ve hissettirerek ifade etmektedir. On iki sene boyunca içinde büyüdüğü şilte eskimiştir ancak ona olan sevgisi artmıştır. Bu bakış Ziya Osman Saba’ya özgü bir tavırdır. Mesut İnsanlar Fotoğrafhanesi’nde de sıkıldığ 1 için gezintiye çıkan kahraman teselliyi ev eşyalarında, bir eşte, aile huzurunu çağrıştıran fotoğraflarda aramaktadır. Behçet Necatigil, Saba'yı bu konuda Tevfik Fikret'in devamı ve Cumhuriyet devri şiirimizde yol gösterici olarak kabul etmektedir: "Tevfik Fikret gibi, Ziya Osman da çeşitli etmenlerde güçleşen hayattan yıldıkça, muhtaç olduğu huzur ve sükûnu evinin mahremiyetinde, sıcaklığında buluyor, yuvasının saadetini hatıra ve hakikatlerle anlatan şiirlerinde bilhassa başarılı ve benzersiz oluyordu. Aile şiirlerinde birey-toplum münasebet ve çatışmalarında ailenin kurtarıcılığını göstermekle, Ziya Osman, Cumhuriyet devri şiirimizde bu konuda bir yol gösterici değerini taşır." (1999: 123).

Anlatım değeri açısından bakıldığında "Mesut İnsanlar Fotoğrafhanesi” adlı hikâye sıradan bir anlatı olarak görülmektedir. Bu durum bize yazıya asıl karakterini kazandıranın yazarın niyeti ile ilgili eserine yansıttığı bağlamsal değerler olduğunu göstermektedir. Yazarın niyeti ve bunu eserine yansıtma şekli, okuyucu ya da eleştirmenin buna yaklaşımı tartı̧̧ma konusudur. 
Bir anlatıda "Her bir varlık, niyetin tecellisi için elele vermiş durumdadır. Dolayısıyla araştırmacı, tek tek unsurları bulup da bırakmak yerine bu elemanların, niyet doğrultusundaki işlevselliğini ortaya çıkarmalıdır." (Tökel 2002: 232). Yazarın niyeti ya da eserin ifade ettiği konusu iki farklı açıdan değerlendirilmektedir. Eserin anlattığı yazarın niyeti midir yoksa okuyucu ya da eleştirmenlerin yorumları mıdır? Moran, yazarın niyeti meselesinde, yazarın amacı olan anlamla, eserin anlamının aynı olmayabileceği kanaatindedir (2007: 141). Bu bakımdan eserin yorumlanmasında son söz de yazara ait olmayacaktır. Zira yazar da eseri karşısında herkes gibi bir okurdur. Ayrıca yazarın eserini ürettikten sonra edindiği izlenim ya da hissiyat yazarken hissettiğinden farklı bile olabilmektedir. Ancak yaratma sürecinin tek şahidi olması sebebiyle yazar, eserini yorumlama noktasinda yine de ayrı bir yeri haizdir. Uygur'a göre, yazarın, eserini yorumlamasının değerce bir üstünlüğü olduğu yadsınamaz ancak bu onu bu konuda biricik yapmaz (1985: 55). Zira yazarlık ve yorumculuk başka başka şeylerdir. Bununla birlikte yazarın eserin meydana gelmeden önceki ve meydana gelme anındaki yaşantıları ve duygulanımları yazara özeldir. Yazarın buna dair bir paylaşımı ya da yazarın bu konudaki bir tespiti eserdeki örtük anlamların ortaya çıkışını kolaylaştıracaktır. Bu bakımdan bir üst dil kullanan eleştirinin gerçekliğinden söz etmek yazar için bile olsa söz konusu olmayacaktır. "Zira eleştiri bir üst dil ise bu demektir ki eleştirinin görevi hiçbir zaman "gerçekleri” keşfetmek değildir, sadece "geçerlilikleri” keşfetmektir.” (Barthes 2003: 740). Bu geçerliliklerin keşfinin; eseri, yazarı ve hatta eserin meydana getirildiği dönemin sosyal ve psikolojik yapısını topyekûn ele almaktan geçtiği daha makul görünse de Barthes bu geçerliliği sadece yazarın dili kullanma biçimde aramanın doğru olduğunu savunmaktadır. Dilden hareket etmeyen her anlamlama çabasının kötü bir üst dile dönüştüğü düşüncesindedir. Ona göre anlam yazarın öz yaşam hikâyesi ya da yetiştiği çevrede değil ürettiği dilde saklıdır. Bu bakımdan Barthes için dil araç değil, amaçtır (Uçan 2003: 222). Buna ilaveten ciddi bir edebi eleştirinin yazarın kimliğinden soyutlanarak yapılması mümkün görünmemektedir. Bir eserin ilk muhatabı ve müesseri şüphesiz ki yazarıdır. Bu bakımdan eser okuyucuya da ilk çağrışımı yazarı açısından yapacaktır. Yazarı tanıyan bir okuyucu eseri değerlendirirken yazarın niyeti hakkında daha gerçekçi çıkarımlarda bulunabilecektir. "Bir metinde onlarca, hatta yüzlerce farklı kişilik görülebilir, ama nihayette bütün bunlar yazarın bağımsız kişiliğinin bağımlı varlıklarıdır." (Tökel 2002: 210). Anlatı kahramanlarını ya da gelişen olaylar, ne kadar objektif ve bağımsız görünürse görünsün yazarın dünyasının, benliğinin, şuuraltının yansımasıdır. "Roman kişisi, yokluktan varlık düzlemine çıktığında, bütünüyle yazarın kendisine tanıdığı imkânlar çerçevesinde ko- 
nuşmaktadır." (Tökel 2002: 210). Bu bakımdan her ne kadar iyi bir anlatıda okuyucu yazarın varlığ asla hissedilmemeli (Tökel 2002: 209) ise de, eleştirmenlerin ya da metin çözümleyicilerin göz önünde bulundurmaları gereken en önemli hususlardan biri, romancinın eserlerinde ne kadar objektif olursa olsun bütün kahramanların yine kendisi olduğu gerçeğidir (Tekin 1999: 49).

Mesut İnsanlar Fotoğrafhanesi hikâyesinin çözümlenmesi anlatım ve niyete dayalı değerler ışığında yapılacaktır. Anlatım değeri, yazarın niyetini vermek için hazırladığı kurgu haritasıdır. Yazarın anlatımın içine sığdırdığı bağlamsal ifadeler onun asıl niyeti hakkında okuyucuya ipuçları sunmaktadır. Her hikâye bir anlatım değerleri bütünüdür ancak yazarı farklı kılan, anlatımsal değerleri sunarken seçtiği bağlamdır. "Yazar adını verdiğimiz kişi belli bir niyet doğrultusunda bir konu seçmekte ve kendi sanatsal dehasını kullanarak seçtiği konuyu çeşitli aracılar vasıtasılyla okuyucunun gözünde görünür kılmaktadır." (Tökel 2002: 209). Yazarın eserini icra ederken bilinçli ya da bilinçsiz olarak seçtiği sözcük ya da tümceler onun niyetini çağrıştırır. Yazar kimi zaman okuyucuda bilhassa bir hissi yaratmak için kimi zaman da gayriihtiyari ve özel bir sebebe bağlı olmaksızın bazı ifadeler kullanır. Bu kullanımlar yazarın üslubu, kimliği, niyeti ve kişiliği hakkında okuyucuyu ve eleştirmeni fikir sahibi kılar. Bu hikâye tahlil edilirken öncelikle yazarın anlatım değerlerini nasıl sıraladığı incelenecektir. Bu yöntemle yazarın niyetini ve niyetini gerçekleştirmek için kullandığı anlatım yolunu daha belirgin olarak gösterilmiş olacaktır.

Özet:

- Hikâyenin kahramanı işten çıkar ve bir gezinti yapmaya karar verir.

- Gezerken etrafi seyreder.

- Etrafindaki insanları gözlemler.

- Dükkânları gözlemler.

- Apartmanları gözlemler.

- Kadın eşyaları satan dükkânları inceler.

- Fotoğrafçıdaki resimlere bakar.

- Bir fotoğraf çektirmeye karar verir.

- Fotoğrafçıya girer.

- Duvardaki fotoğrafları inceler.

- Burada fotoğraf çektiren herkesin mutlu olduğunu düşünür. 
- Fotoğrafçıya kendisinin de bir fotoğraf çektirmek istediğini söyler.

- Mutlu şeyler düşünmesine rağmen yüzünde bir türlü mutlu bir tebessüm oluşturamaz.

- Nihayet fotoğrafçı bu durumda fotoğrafını çekemeyeceğini söyler.

\section{Anlatım Değeri:}

- İşten çıkması

- Haliç ve Boğaziçi'ni geçerek gezinmesi

- Cadde boyunca insanları ve mağaza vitrinlerini seyretmesi

- Bir fotoğrafçıya girip bir fotoğraf çektirmek istediğini söylemesi

- Mutlu görüneceği bir resim çektirmek istemesi fakat bir türlü başaramaması

- En sonunda fotoğrafçının resmini çekemeyeceğini söylemesi

\section{Niyet ile İlgili Değerler:}

Hikâye, "O akşam işimden erken çıkabilmiştim." cümlesi ile başlar. "Çıkabilmiştim" ifadesi parçanın en başında kahramanın işten çıkmaya çabalad1ğını gösteriyor. Hikâyenin başında kapalı mekândan açık bir ortama çıkış bir rahatlama ifadesidir. Ziya Osman Saba, bu hikâyeyi memuriyeti esnasında yazmıştır. O, hakkında yazılanlarda da vurguladığı üzere bu işi severek yapmamaktadır. İşten çıkışını yeterlik fiili ile ifade edişi ve bu ayrılışı bir nevi tutsaklıktan kurtuluş gibi yansıtması bu düşünceyi desteklemektedir. Yani sıkılmıştır.

Yazarın birkaç cümleye "işte" diye başlaması, yarım saat aralıklı vapur isimlerini söylemesi eski hayatının hareketliliğini sezdirmek istemesindendir. Bu hareketli ifadelerin hemen ardından yazar şu anki yalnızlığına döner. "Acı zil sesi ve demir kapı" gibi soğuk ve sevimsiz ifadeleri de daha sonra ifade edeceği yalnızlık duygusuna hazırlayıcı olması için vermiş olmalıdır. Yazar önceleri, bu vapurların gittiği yerlerdeki bekleyenlerine ulaşabilmek için vapuru kaçırmak korkusu yaşıyormuş fakat artık kimsesi kalmamıştır. Yalnızdır. Telaş etmesine gerek yoktur. "Bir zamanlar saniyeleri bile kıymetli olan bu kâh küsurlu kâh küsursuz rakamlar şimdi benim için eski ehemmiyetlerini 
ne kadar kaybetmişler!" (Saba 2004: 13)². Kahramanın o anda fark ettiği bu durum kendisini de şaşırtır. Eskiden yapmak istediği ancak hayatının hareketliliğinden zamanının yokluğundan yapamadığı pek çok şeyi rahatlıkla yapabileceği için aslında memnun olmalıdır. Kahraman her ne kadar bunu teselli gibi görse de pek memnun değildir. Çünkü onun vapura binerek aceleyle gidecek kimsesi de kalmamıştır. "Ben artık o vapurların yolcusu değilim, benim oralarda kimsem kalmadı. Yüksekkaldırım'dan istediğim kadar yavaş, eski kitap satan dükkânların camekânları önünde istediğim kadar oyalana oyalana çıkabilirim.” (s.13). Hikâyenin ilerleyen satırları bize gösterecek ki yazarın asıl niyeti vaktinin çokluğundan duyduğu memnuniyeti vurgulamak değildir. Vaktinin çokluğuna neden olan yalnızlığını vurgulamaktır. Bir aile ya da eşin yokluğu mutsuzluğunun asıl nedenidir. Yol boyunca kendisini mutlu etmesi gereken her şeyi denediği hâlde mutsuzluğunun nedenini en son bulacaktır. Bu durum aslında yazarın etrafinda mutlu mesut akıp giden bir kalabalığın karşısında kendi mutsuzluğunun yarattı̆̆ı tezadı hissettirebilmek içindir.

Bir sonraki paragrafta da yazar kalabalığın içinde gözlemlediği her durumda yalnızlı̆̆ını vurgulamaya çalışır. Şöyle ki, yazar anlattıklarıyla kalabalık bir şehir manzarası çizer. Bu manzaranın içinde biz kahramanı tecrit olmuş görürüz. Bu manzarada aslında her şey zıddıyla bir araya gelip bütünleşmiştir. Uzun boylu-kısa boylu, erkek-kadın, arkadan gelenler-karşıdan gelenler vs... bütün bu tezatlar kompozisyonu içinde yalnız kendisinin bir karşıtı yoktur. Kendisine bir yer bulamıyor gibidir. Kalabalığın en az mutlu olması beklenen grubu, ayağı çıplak çocuklar bile en az ayağı korunaklılar kadar mutludur. Öyleyse bu zitliklardan örülü kompozisyonun fonuna mutluluğu yerleştirmiştir yazar. Kalabalık bir caddede birbirinin ziddı onlarca insanın hepsi mutludur. Henüz hikâyenin başında bu kalabalığın mutlu oluşunun ya da mutsuzluğunun maddi varlıkla ilgili olmadığını yazarın çağrışımlarından anlıyoruz. Zira ömrün hazinesi genç kızlardır. Ve ayağı yalın çocuklar da ayakkabılılar kadar mutludur. Para ve maddi varlık onların ancak mutluluklarını arttırabilir. Gazete alan zenginlerin para üstünü almaması yahut vitrinlerdeki eşyalar, ancak mutluluğu arttırabilir. Bütün bu kalabalık içinde bahsi geçen vasıfların hepsini haiz insanlar çoğul eki almış şekilde tavsif edilir. "Erkekler, kadınlar, uzun boylular, kısa boylular, yaşlilar, gençler, güzeller, çirkinler, zenginler, fakirler..." (s. 14). Ancak yazar tekildir. Yani neresinden bakarsa baksın birbirleriyle bir şekilde benzerlikleri ve uyumları olan bir insan kalabalığı karşısında yalnız ve tekildir. Herkes mutludur. Yalnız kahraman, bu kompozisyondan her türlü soyutlanmıştır ve kendini o kalabalığa ait hissetmek istemektedir. Bir şekilde kendisi de bu kalabalıkla uyumlu ve bütün olabilmek istemektedir. 
Bu durum yazarın ruh hali ile alakalıdır. Mutsuz olan ve yalnızlıktan şikâyet eden kahraman etrafindaki herkesin mutlu ve kalabalıklar içinde olduğunu düşünmektedir.

Hikâyenin devamında, yazar bu kalabalığı mutlu eden şeyin mağaza ve dükkânlar olduğunu düşünüp oralara yönelir. Yazar, önceki paragrafta mutluluğu, tezatlardan örülü kompozisyonun fonuna koyarken burada uyumların ardında bulmaya çalı̧̧ı. Önce güzel yemek odasında "uyumlu" bir çiftin mutluluğunu hatırlatır. Daha sonra değişik mağazalardaki değişik eşyaların uyumunu ve tüm bir evin içindeki uyumu düşünür. Uyum kelimesi de zitlık kelimesi gibi en az iki varlığı gerektiren kavramlar için kullanılır. Bu bakımdan yazarın uyum ve zıtlık kavramlarına vurgu yapması da manidardır. Hikâyenin kahramanı yalnızlı̆̆ın verdiği ruh hali içinde zıt ya da uyumlu, yalnız olmayan herkesin mutlu her şeyin mutluluk telkin edici olduğu imgesini yaratmaya çalışmaktadır. Gözlemlediği odalardaki perdelerin arasından görünen kış dekoru ve odanın kızıl bir aydınlık içinde olması ifadeleri yazarın sıcak yuva düşündürmek istemesindendir. Bununla birlikte şehrin en büyük mobilyacısının teşhirleri arasında özellikle bir yatak odasını ayrıntılarıyla betimliyor oluşu, kahramanın aile hayatı ve mahremiyetine duyduğu özlemi; paragrafın sonunda bu mobilyaların sahiplerini görmeye sabırsızlandığını sanmasıyla aslında kendisinin aile saadetine duyduğu iştiyakı sezdirmektedir.

Hikâyenin buraya kadarki bölümlerinde yalnızlıktan kaynaklandığını sandığımız bir iç sıkıntısıyla dışarı çıkan kahramanımızın sıcak bir ev hayal etmesi, mobilyaların uyumunda huzur bulması, kendisi için bir apartman dairesi beğenmesi, yalnızlı̆̆ını ve dolayısı ile mutsuzluğunu bir yuva ile giderebileceği düşüncesi içine girdiğini gösterir. Mutlu bir yuva ancak bir eş ile sağlanır. Bu da kahramanımıza kadınları düşündürmüş olmalı. Zira "İlerliyorum” diyerek geçtiği bir sonraki bölümde kahramanımızı kadın eşyalarına bakarken görürüz. Burada bir parantezle "İlerliyorum" ifadesine değinebiliriz. Sıkıntısına çözüm arayan kahramanın buraya kadar aradığını bulamadığını da çağrıştırır. Aradığ 1 belki daha ileridedir. Aslında bu, kahramanın gelecekten umudunun bilinçaltı yansımasıdır. Aradığı mutluluğu mutlaka ileride bir yerlerde ve bir zamanda bulabileceğini hissediyor olmalıdır. İlerlerken aslında kafasında evin içinde onu mutlu edecek kadın vardır. Vitrinden beğendiği mavi kolyenin, tanıdığı mavi gözlü kıza çok yakışacağını düşünür ve belki de bunu onun için satın almayı düşünür. Böylece mutlu olacaktır. Fakat "O kız onun sevgilisi değildir." Burada yazarın asıl niyeti ortaya çıkmaktadır. Ne o mavi gözlü kız ne de başkası onun sevgilisidir. Bu yüzden o kolyeyi alamaz. Buradaki, “Tanıdığım kızlardan şu en mavi gözlüsüne ne kadar yaraşacak!” ifadesi ile hikâyenin başından beri bütün eşyaları birbirine ya da evlere uydurmaya/ 
birleştirmeye çalışan kahraman, burada bir eşya ile bir insanın uyumundan bahsetmektedir. Bu durum bize kahramanın mavi gözlü kızla kendisinin uyumunu da düşünmüş olduğunu hissettirir. Çünkü baktığı bütün eşyaları kendi hayatında hayal etmişti. Bu aşamadan sonra kahramanın sürekli kadın eşyalarına bakması da mavi gözlü kızın zihninde çağrıştırdığı eş fikrinden kaynaklanmış olmalıdır. Sonra kadın terliklerine bakar. Bu bakıştan bütün bir ev hayatını hayal edebilir. Çünkü bütün ev hayatını yapan o terliklerin içindeki kadındır. Kahraman, kadın eşyalarına da bakarak, yine aynı düşünce ile alacağı kimsesi olmadığından yalnızlığını hatırlar. Yazarın cümlesine "ah" ile başlaması bu duruma gerçekten içerlediğini göstermektedir. Ayrıca, yazarın giysi isimlerini iç giyimden dış giyime doğru kadını baştan ayağa giydirir gibi sırayla saymış olması da manidardır. Bu durum yazarın hayalindeki kadını tüm mahremiyetiyle sahiplenme arzusunu gösterir: "Ah şu kadın eşyaları, çamaşırları, elbiseleri satan mağazalar... Düşünüyorum ki, bütün o çamaşırlardan, elbiselerden, tayyörlerden, mantolardan istediğim kadar alacak param olsa da, onları kullanabilecek, onları giyebilecek, 'Bütün bunlar senin için' diyebileceğim kimsem yok.” (s. 15). Yalnızlığı o kadar mutsuz etmekte ve bundan kurtulmak istemektedir ki ilk aklına gelen ya da o an elinden tek gelen onu satın alabilmektir. Ancak nafile, parasının olması kifayet etmemektedir.

Kahraman ardından yönünü diğer mağaza ve dükkânlara çevirir. "Bütün bu mağazalar şu insanlara mutluluk satıyor" (s.15) cümlesindeki "şu insanlar" ifadesi kahramanın kendisini, gördüğü o insanların dişında hissettiğinin başka bir ispatıdır. Zira "biz insanlara" da diyebilirdi. Yani kendisi o mağazaların sattığı mutluluktan alamayacaktır. Çünkü mesela manavdaki sarı portakallar "bir sofra mutluluğunu tamamlamak" içindir. Sofra kavramı ise yalnız olmayanlar için geçerli olabilir. Yani bir aile için. Oysa kahramanımız içindeki eksiklikten dolayı mutsuzdur. Ve belki tamamlanma arzusu ile dükkânları gezmektedir. Kısaca, yalnız bir insanı tek başına mutlu edecek bir yemiş yoktur. Yukarıda biz kahramanın içindeki eksikliği bir eşle gidermeye çalıştığını görmüştük. Burada ise içindeki boşluğu bir aile saadeti ile doldurmak istediğini anlıyoruz. Sofra, portakal ve boza imgeleri birleşerek bir ailenin kış akşamlarındaki huzurunu tablolaştırmaktadır. Sofra aileyi bir araya toplamaktadır. Sofranın saadete dönüşmesi için aile olmak gerekir. Bu saadeti tamamlayan ise tadı kokusu lezzeti ile yemeğin ardından sahneye çıkan portakallardır. Kahraman, portakalın görüntüsünden kış akşamlarında huzurlu bir aile ortamının kokusunu içine çeker gibidir. Yemekten birkaç saat sonra ise boza içilerek şahsına münhasır saadet yaşanacaktır. Bunlar ortalama bir ailenin sıradan akşam seremonileridir. Aslında yaşanırken çok büyük anlamlar yüklenmeyen bu günlük rutinler yazarın bilinçaltında saadetle birleştirilmiş- 
tir. Bu kompozisyonun içindeki bir parça, bütünü çağrıştırmaktadır. Bütün sofra saadetini portakal yaşatır. Burada kokuların ve tatların anımsatma ya da çağrışım konusundaki gücü de vurgulanmış olur. Kahraman, buraya kadar baktığ 1 her şeyi mutlu bir aile tablosu içine yerleştirir. Böylece her defasında yalnızlığını ve mutsuzluğunu hissettirir.

Kahraman, mutsuzdur ve ona göre etrafındaki herkes daha mutludur, bu bakımdan o caddede mutsuz insan yoktur. Bu mutlu insanlar da mutluluklar1$\mathrm{n} 1$ tespit ettirmek için fotoğraf çektirirler. Kahraman, fotoğrafçı vitrinindeki fotoğraflara uzun uzun bakar. Mutlu insanların tebessümleri o kadar canlı ve gerçektir ki bu insanların hiçbirinin ölmüş olamayacağını düşünür. Hatta fotoğraftakilerin ileri yaştaki hallerini caddede gördüğünü düşünür. Bu cadde o kadar saadet doludur ki en yakın mezar kilometrelerce uzaktır. Ona göre saadeti bozacak tek şey ölümdür. Bu cadde bu kadar mesutsa mezarlık/ölüm oldukça uzak olmalıdır. Zira Saba’nın bütün saadetini nihayete erdiren annesinin ölümüdür.

Hikâyenin bu bölümüne kadar mağaza ve dükkânlarda satılanların hep başkalarını -yalnız olmayanları- mutlu etmek için olduğunu düşündüğünden buradan sonra kendisi de mutluluk satın almayı dener. Hayalinde satın almanın kendisini mutlu edeceği şeyleri düşünürken gözü yeniden fotoğrafhaneye ilişir. Mesela mesut insanların fotoğraflarını görür, "Ben de mesudum, benim de fotoğrafımı çekebilirsiniz." demeyi düşünür. Hemen ardından fotoğrafçının, "Sizin sevgiliniz yok, fotoğrafı ne yapacaksınız?" deme ihtimalini düşünür. Oysa bu cümleyi sarf eden kahramanın bilincidir. Çünkü kimsesi olmayan insanlar yalnızdır ve yalnız insanlar mutsuzdur. Mutsuz insanın da fotoğrafi çekilmez. Hikâyenin kahramanı mutsuz olduğunu kendi kendisine itiraf edemez fakat o fotoğrafı çektirirse mutlu insanlardan biri olacağını düşünmektedir. O kendisine mutluluk bahaneleri arar. Bu bahaneler hep geleceğe yöneliktir. Mesela, çektireceği fotoğrafa çeşitli nedenlerle bakacak insanları düşünüp en güzel fotoğrafinı çektirmek ister: "Elbette günün birinde benim de bir sevgilim olabilir. Sizin çekeceğiniz bu en güzel fotoğraf, onun çantasının gizli bir köşesinde, güzel kokular içinde yatabilir. (...) "Yeni bir şiir kitabım intişar etti... Kim bilir, zaman gelir, edebiyat tarihçisi, bu kitabın intişar ettiği zamanki fotoğrafımı arayabilir.” (s.16)

Fotoğrafhanenin önünde bekleyen gelin arabası kahramanımızın dikkati aç1sından önemlidir. O yalnız ve mutsuzdur, oysa gelin ve damat hem birlikte hem mutludurlar. Burada kahramanın yalnızlığı bir kere daha vurgulanır. Gelin ve damat mutludur, bu yüzden fotoğraf çektirmeyi hak etmektedirler. Buna mukabil, kahramanın mutluluk için bahanesi bile yoktur. Fotoğrafha- 
neye girme cesaretini bu çiftten alacaktır. Fotoğrafhaneye girmek için düşündüğü bahanelerden biri en mutlu anlarında bu çifti bir kere selamlayabilmektir. Fotoğrafhanedeki resimlere bakar. Resim çektiren bütün insanların mutluluk için bir sebebi vardır. Kimisi mezun olmuştur, kimisi evleniyordur.

Burada dikkatimizi çeken bir diğer husus da kahramanın resimleri gözlemlerken izlediği sıradır. Önce, en gençlerin, çocukların, öğrencilerin ve genç subayların bir sebebe bağladığı mutluluklarını gösteren resimlerine dikkat eder. Sonra yine evlilere döner ve burada "evliler" sözünü oldukça sık tekrarlar. Sanki bu kelimeyi söyleyerek bile mutlu olacağını düşünmektedir. Kahramanın resimleri incelerken yaş sırası izlemesi ve hiç yaşlı resmi olmadığını söylemesi bize onu mutsuz eden unsurlardan birinin bu yaş meselesi olduğunu düşündürmektedir. Evlilerin resimlerine de bu yaş sırasıyla bakar. Zira daha fotoğrafhane vitrini incelerken bu mevzuyu bir daha gözden geçirip her ne kadar mutsuzluğundan dolayı daha yaşlı görünse de gençliğinin mesut pozu vermesi için gerekli tebessümü yaratacağını düşünür. Bütün resimlerdekiler, mutlulukları resimlerden dışarı taşarcasına mutludur. İhtiyar, çirkin ve düşünceli insan resmi yoktur. Bu durum kahramanın aklına iki ihtimali çağrıştırrr: Ya buraya hiç mutsuz kimse gelmemiş yahut fotoğrafçı sevinçsiz insan resmi çekmemiştir.

İşliğin kapısı açıldığında çıkan gelin "elindeki çiçeklerden daha beyaz beyazlar içinde"dir. Buradaki gelini saran daha beyaz beyazlar onun mutluluğudur. Yazarın damat için, "genç koca" deyişi, "ilkyaz havası" ve "ilkyaz yeli" gibi ifadeleri hep birlikte düşünülürse yazarın bu gençliğe, tazeliğe ve bunun sağladığı mutluluğa imrenmiş olabileceğini söyleyebiliriz. Fotoğraf̧̧ı da eserinden mutludur. Mutsuz olan kahramanı önce fark etmez. Fark ettiğinde ise karşısındakinin mutsuzluğu onu endişelendirir.

Hikâyenin kahramanı, önce güzel şeyler düşünerek mutlu bir resim çektirmeyi düşünür, başarısız olur. Sonra ise bu resmin kullanılacağ1 yerleri düşünerek mutlu görünmeye çalışır, yine başarısız olur. Birçok uğraştan sonra yazar kendisini aldattığını fark eder. "Asıl mesut zamanlarım" ifadesinden şu anda mutlu olmadığını anlıyoruz. Yalnız değilken, onu mutlu gösterecek şeyleri düşünmesine gerek kalmadan, mutlu görünüyorken fotoğraf çektirmediği için hayıflanır. Tam bu sırada bu duruma bir antitez üretir ve bu da, hikâyenin temasını ihtiva eden ana görüştür. Yazar dünyada her insanın yıkıma uğramış olabileceğini, bunun için kötümser olunmaması gerektiğini düşünür. Yıkımlar yerine mutlulukları, ölümler yerine doğacakları, geçmişler yerine gelecekleri koymaya karar verir. Aslında tam gerçekten mutlu olmaya yöneldiği anda fotoğrafçı fotoğrafını çekemeyeceğini söyler. Hikâyenin bu son kısmı kahra- 
manın yol boyunca karşılaştı̆̆ı tek somut olumsuzluktur. Öncesinde olumsuzluğun kaynağı hep yazarın umutsuzluğuydu. Bütün o kalabalığın dışında görüyordu kendisini. Şimdi ise, her ne kadar mutlu bir fotoğraf çektiremediyse de diğer insanlar gibi o fotoğrafhaneden mutlu bir insan olarak çıacak ve mutluluk satın almaya gidecektir.

Hikâye boyunca biz kahramanın içinde bulunduğu ortamın çağrıştırdığ1 s1kıntı ve ferahlık hislerinin tezat arz edecek şekilde art ada kullanıldı̆̆ını görmekteyiz. Çünkü sıkılan kahraman ferahlamak ister ve arada anlık da olsa ferahlık hissine şahit oluruz. Ama bunlar kahramanın ufak aldanışlarıdır ve geçicidir. Tekrar yerini kesif bir bunalıma bırakır ancak kahraman arayışını sürdürür. Ve en sonunda kahraman, maddi varlıklarda aradığı mutluluğu kendi içinde ve zihni bir telkinle elde eder. Derin bir sıkıntı ile başlayan hikâyenin gerçek bir umut ve ferahlama hissi ile sona erdiğini görmekteyiz. Aslında bu durum, içindeki sıkıntının sebebini etrafindaki her şeye yansıtmaya çalışan, sıkıntısının sebebini de çözümünü de eşyada ve mekânda bulduğunu sanan modern bireyin anlık, geçici mutluğu ile sürekli umutsuzluğunun tezadıdır.

\section{Sonuç}

Edebi metinler diğer metinlerden farklı olarak daha ziyade sezdirme esasına dayalı biçimde kaleme alınırlar. Bu bakımdan eserin çağrışım değeri ile anlatım değeri arasında belirgin farklar olabilmektedir. Ziya Osman Saba, çocukluğunun güzel günlerini bütün hayatına teşmil eden, içinde bulunduğu hayatı çocukluğunun algıları ile değerlendirmeyi yeğleyen o günlere duyduğu özlemi hem hikâyelerinde hem şiirlerinde sık sık çağrıştıran bir yazardır.

Mesut İnsanlar Fotoğrafhanesi, anlatımsal değerler 1şı̆̆ında işten çıkan bir adamın yol boyunca mağazaları incelemesi ve bir fotoğrafhanede fotoğraf çektirmek istemesi ve başaramamasını konu edinir. Oysa hikâyeyi yazarın niyeti noktasından okuduğumuzda karşımıza içinde eksikliğini hissettiği mutluluğu mağazalardan ve en son olarak da bir fotoğrafhaneden almaya çalışan birey görülmektedir. Hikâye sonunda mutluluğu içinde bir yerlerde bulmak konusunda kendisini telkinle huzura erdiren modern birey ortaya çıkar.

Anlatıdaki her unsurun yazarın niyetine hizmet ettiği gerçeğinden yola çıkarak yaptı̆̆ımız hikâye incelememizde öncelikle yazarın kurgusunu oluşturma biçimi değerlendirilerek olay örgüsü çıkarıldı. Çalışmanın diğer bölümünde yazarın asıl niyetinin, anlatımı nasıl şekillendirdiği belirlenmeye çalışıldı. Böylece yazarın anlatımının niyetine hizmet etme biçimi, malzemesini seçerken izlediği yol belirlendi. 
Her ne kadar Ziya Osman'ın hayatı çerçevesinde okumuş olsak da bu hikâye; içinde hissettiği her eksikliği tüketime yönelerek gidermeye çalışan modern insanın trajedisini de vermektedir. Modern insan, manevi ihtiyaçlarını da maddi varlıkla tatmine çalışmaktadır. Bu durum, varlığı çok olanın mutluluğu da çok olur gibi bir izlenim yaratmaktadır. Oysa yüzyıllar önce Yunus Emre bu sırrı: "Bunca varlık var iken gitmez gönül darlığı" diyerek çözmüştür. Aile mutluluğu için ev; evin içindeki saadeti elde etmek için bir kadın yerine kadın ve ev eşyalarına sahip olmak yetmiyor... Hikâyedeki bütün o kalabalık ve alışveriş manzarası satın alarak eksikliği giderme çabası telkin etmektedir. Kahramanın da önemli bir eksiği vardır ancak bugünkü tüketim anlayışı bazı eksiklikleri tamamlamaya muktedir değildir. Maddi alı̧veriş sadece var olan huzuru pekiştirebilir. Ya da huzurla birlikte anıldığı, var olduğu için bilinçaltı çağrışımla huzurun ve saadetin sebebi imiş gibi görünüyor olabilir. Bu bakımdan günümüz insanı içinde hissettiği bütün manevi eksikliği alışverişle gidermeye çalı̧̧maktadır.

Ziya Osman Saba, bu küçük hikâye ile içindeki büyük dünyanın kapılarını okuyucuya açmaktadır. Her okuyucu o dünyada kendisine bir yer edinebilmektedir. Zira hikâyedeki adamın yalnızlığını ve sıkılmışlı̆ıını tarifi, modern insanın dramına çok benzerdir. Her ne kadar hikâyenin kahramanı sıkılmış olsa da Saba’nın naif ve masalsı üslubu bu yalnızlığın ve bunalmışlı̆ın ağırlığını okuyucuya hissettirmemektedir. Bu bakımdan yazarın niyeti ilk etapta anlaşılamamaktadır. Yazarın eser boyunca kullandığı ifadeler, takılar ve hatta cümle yapıları ayrıntılı izlendiğinde karşımıza iş sonrası gezintiden çok daha fazlası çıkmaktadır.

\section{Kaynaklar}

Barthes, Roland (2003). "Essais Critiques, (Eleştiri Nedir?)”, Hece Eleştiri Özel Sayısı, Gev. Hilmi Uçan. Ankara: 740-744.

Kırc1, Mustafa (2010). Hüzünlü Anlar Fotoğraf̧̧ısı Ziya Osman Saba, İstanbul: Kitabevi.

Kudret, Cevdet (2009). Türk Edebiyatında Hikâye ve Roman, c. 3. İstanbul: İnkılap Yayınevi.

Miyasoğlu, Mustafa (1999). Ziya Osman Saba, Ankara: Akçă̆ Yayınları.

Moran, Berna (2007). Edebiyat Kuramları ve Eleştiri, İstanbul: İletişim Yayınları.

Necatigil, Behçet (1999). “Ziya Osman’a Devam” Düzyazılar 1, Yap1 Kredi Yayınları, İstanbul: 121 - 126. 
(2003). Edebiyatımızda Eserler Sözlüğ̈̈ 229 Çağdaş Yazarımızın 770 Eseri, İstanbul: Varlık Yayınları.

Önertoy, Olcay (1979). “Ziya Osman Saba’nın Küçük Hikâyeciliğì”, Türkoloji Dergisi 8/1: 79-86.

Saba, Ziya Osman (1992). Mesut İnsanlar Fotoğrafhanesi/Değişen İstanbul, İstanbul: Varlık Yayınları.

(2003). Mesut İnsanlar Fotoğrafhanesi (Bütün Öyküleri), İstanbul: Alkım Yayınevi.

(2004). Yazılar, Söyleşiler, Mektuplar: Konuşanlar, Bir Hüzünle Sesinde, İstanbul: Alkım Yayınevi.

Tekin, Mehmet (1999). Romancı Yönüyle Peyami Safa, İstanbul: Ötüken Yayinlar1.

Tökel, Dursun Ali (2002). "Niyet Boyutundan Kurmacayı Okumak: Yazarın Niyeti Romanın Oluşumu”, Hece, Aylık Edebiyat Dergisi, Roman Özel Sayısı, S. 65/66/67, Mayıs-Haziran-Temmuz. Ankara: s.202-237.

Uçan, Hilmi (2003). Edebiyat Bilimi ve Eleștiri, Ankara: Hece Yayınları.

Uygur, Nermi (1985). İnsan Açısından Edebiyat, İstanbul: Remzi Kitabevi.

Uygur, Selda (2005). Türler Arası İlişkiler Açısından Ziya Osman Saba’nın Şiir ve Öyküleri, Yüksek Lisans Tezi, İstanbul: Marmara Üniversitesi Türkiyat Araştırmaları Enstitüsü Türk Dili Ve Edebiyatı Ana Bilim Dalı Yeni Türk Edebiyatı Bilim Dalı.

\section{Sonnotlar}

1 İlk baskısı Varlık Yayınları tarafindan yayımlanan bu kitapta toplam dokuz öykü bulunmaktadır. Varlık Yayınları tarafından neşredilen ikinci nesir kitabı "Değişen İstanbul"da ise altı anı bulunmaktadır. 1992 yılında yine Varlık Yayınları tarafından iki anı-öykü kitabı birleştirilerek yeniden yayımlanmıştır (Saba 1992). 2003 yılında ise "Bütün Öyküleri, Mesut İnsanlar Fotoğrafhanesi” adıyla Alkım Yayınevi tarafından yeniden neşredilmiştir (Saba 2003).

2 Hikâyeden yapılan bu ve diğer bütün alıntılar için eserin bu baskısı kullanilacaktır. 